\title{
IMMUNIZATION AGAINST FELINE CORONAVIRUSES
}

\author{
Fredric W. Scott \\ Department of Veterinary Microbiology, Immunology and Parasitology \\ Cornell Feline Health Center \\ College of Veterinary Medicine \\ Cornell University \\ Ithaca, New York
}

\section{INTRODUCTION}

There are several coronaviruses that infect the domestic cat as well as other members of the family Felidae. Some are primary infections of the cat while others are viruses that produce primary infection in other species of animal or humans but on occasion may also infect the cat. There have been several reviews on these feline coronaviruses and their infections in the cat in recent years. $1,2,5,14,15,22,25,26,38$

Several investigators have attempted to develop effective and safe vaccines against certain of the feline coronaviruses in order to protect cats against severe and of ten fatal disease caused by some of these viruses. One does not have to work with this group of viruses for very long before one develops a genuine respect for them. One soon realizes that the host-virus interaction is different from that of most other viruses that infect cats.

A number of misunderstandings exist about some of these viruses, the accuracy and interpretation of the tests used to diagnose these infections, $1,2,3,20,24,25,37,46$ and the relative importance of each of these viruses in the cat. Some of these coronaviruses are severe pathogens for the cat while others apparently are either nonpathogenic or at most mildly pathogenic for cats. The role of feline coronaviruses in reproductive and neonatal diseases is unclear. $33,40,42$

This manuscript is an attempt to discuss these feline coronaviruses with particular emphasis on the severe pathogen feline infectious peritonitis (FIP) virus, to review what is know about the immunogens of FIP virus, and to review some of the research toward developing a vaccine for FIP.

\section{THE VIRUSES INVOLVED}

The coronaviruses known to infect the cat are listed in Table I, with information on the original isolation listed in Table II. The most important of these viruses are those that cause FIP. Although more research is needed to clarify the situation, it appears that there are at least two general groups or "types" of feline infectious peritonitis virus (FIPV). $28,32,33,38,39$ The first group contains viruses that are difficult to isolate in cell culture, with only small amounts of virus produced in 
TABLE I

Feline Coronaviruses that have been identified and Partially Characterized

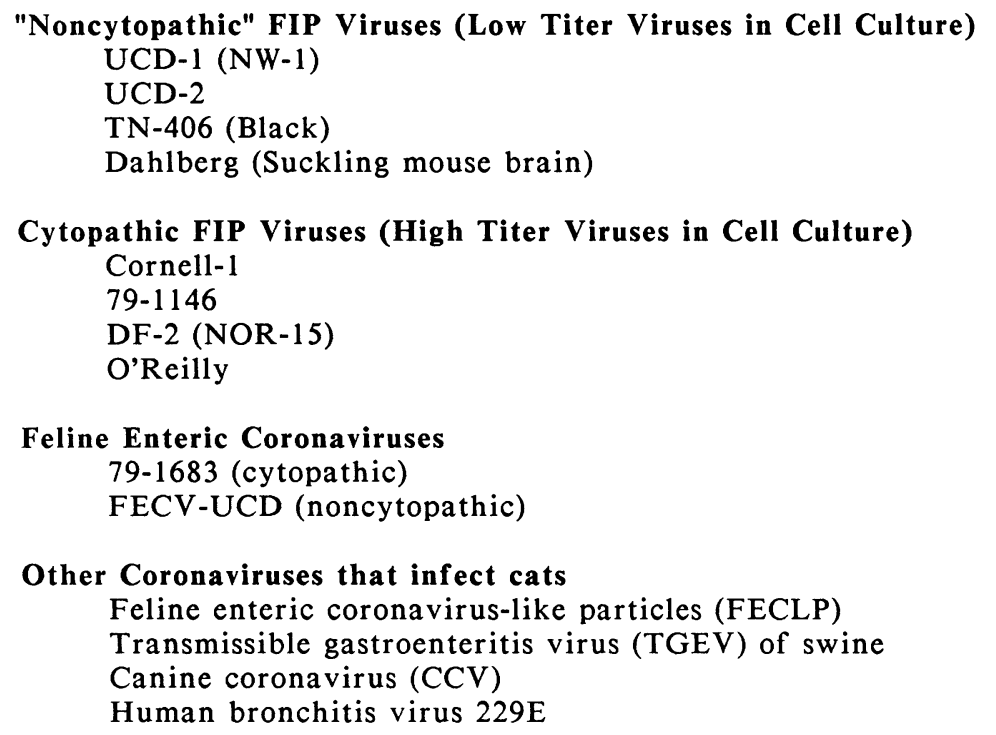

TABLE II

Summary of Clinical Signs Produced and the Original Source of Isolation of Feline Coronavirus Isolates

\begin{tabular}{|c|c|c|c|}
\hline Virus & Clinical Signs & Source of Isolate & $\begin{array}{l}\text { Isolated by } \\
\text { (Reference) }\end{array}$ \\
\hline $\begin{array}{l}79-1146 \\
79-1183 \\
\text { NOR-15 }\end{array}$ & $\begin{array}{l}\text { Neonatal death } \\
\text { Fatal enteritis } \\
\text { FIP }\end{array}$ & $\begin{array}{l}\text { Lung, liver, spleen } \\
\text { MLN, intestine } \\
\text { Spleen }\end{array}$ & $\begin{array}{l}\text { McKeirnan } 18,32 \\
\text { McKeirnan } 18,32 \\
\text { Evermann }\end{array}$ \\
\hline $\begin{array}{l}\text { UCD-1 } \\
\text { UCD-2 } \\
\text { UCD-3 } \\
\text { UCD-4 }\end{array}$ & $\begin{array}{l}\text { FIP } \\
\text { FIP } \\
\text { FIP/leukemia } \\
\text { FIP/leukemia }\end{array}$ & $\begin{array}{l}\text { Ascitic fluid } \\
\text { Ascitic fluid } \\
\text { Ascitic fluid } \\
\text { Ascitic fluid }\end{array}$ & $\begin{array}{l}\text { Pedersen } 23,30 \\
\text { Pedersen } 33 \\
\text { Pedersen } 33 \\
\text { Pedersen }^{33}\end{array}$ \\
\hline $\begin{array}{l}\text { COR-1 } \\
\text { Dahlberg } \\
\text { TN-406 } \\
\text { O'Reilly }\end{array}$ & $\begin{array}{l}\text { FIP } \\
\text { FIP } \\
\text { FIP } \\
\text { FIP }\end{array}$ & $\begin{array}{l}\text { Liver, Spleen } \\
\text { Liver } \\
\text { Peritoneal Cells } \\
\text { Ascitic fluid }\end{array}$ & $\begin{array}{l}\text { Baines }^{*} \\
\text { Osterhaus } 21 \\
\text { Black } \\
\text { O'Reilly } 19\end{array}$ \\
\hline
\end{tabular}

*J. Baines and F. Scott. Cornell University. Unpublished data, 1986.

$\mathrm{MLN}=$ Mesenteric lymph node

infected cell cultures, yet these viruses produce severe FIP when inoculated into cats. We refer to these viruses as "noncytopathic" FIP viruses, realizing that the term is not completely accurate since under appropriate conditions some cytopathogenicity does occur in cell cultures infected with these viruses.

The second group of FIP viruses contains viruses that are common enteric viruses similar to canine coronavirus, are easily isolated in the laboratory from 
infected cats, produce large amounts of virus in cell cultures with extensive cytopathic effect on the cells, and generally produce a mild or subclinical disease but on occasion can produce fatal FIP.

Evidence is contradictory concerning the antigenic relatedness of these 2 groups of FIPV, but there are cross reactions between these viruses. Certainly these two "types" behave differently in cell cultures, but both can produce clinical and fatal FIP. It has been known for several years that some cats with severe clinical FIP do not have detectable serum antibody titers to the standard commercial feline coronavirus antibody tests. This may be due to either aggregation of virus and antibodies, or to multiple serotypes of virus. There is general agreement that there are multiple biotypes of FIPV, but the question of multiple serotypes remains open.

There are at least 2 strains of feline enteric coronaviruses (FECV). One (FECV-UCD) was isolated by Pedersen et al. ${ }^{31}$ from kittens with mild enteritis. Morphologically and antigenically it is indistinguishable from FIPV. The second FECV (79-1183) was isolated by McKeirnan et al. ${ }^{18}$ The question then must be asked "Are these distinct coronaviruses of cats, or merely intestinal adapted strains of FIPV?" There are arguments for both positions, and only further research will determine the true relationship. It appears that there is a correlation between the ability of the coronaviruses to infect monocytes and their potential to produce systemic disease ending in FIP. ${ }^{43}$ The enteric coronaviruses appear to lack this ability to infect monocytes and therefore the infection remains localized.

At least 3 other coronaviruses of the FIPV antigenic cluster group have been shown to infect cats, at least experimentally (Tables I,III). 4,6,13,20,26,34,35 These infections result in shed of virus from the respiratory tract, oropharynx or the gastrointestinal tract, and seroconversion to the coronavirus antibody tests (Table II). Transmissible gastroenteritis virus (TGEV) of swine results in asymptomatic infections of cats with shed of virus for several weeks. Canine coronavirus (CCV) produces asymptomatic infections with viral shed from the oropharyn $x,{ }^{6}$ while a similar asymptomatic infection occurs with the human bronchitis coronavirus serotype $229 \mathrm{E} .{ }^{4}$ Both CCV and $229 \mathrm{E}$ produce seroconversion to the coronavirus antibody tests, but neither create sensitization in the cat nor produce protection against virulent FIPV exposure. 4,6

Coronavirus-like particles (CVLP) have been observed in the feces of several species including the cat. ${ }^{16,42}$ These are infectious particles with persistent enteric infections. No specific disease condition has been established to be caused by CVLP infection in the cat, but CVLP's have been observed by electron microscopy in the feces of cats with diarrhea. ${ }^{8}$

TABLE III

FIPV-Related Viruses and their Infections in Cats

\begin{tabular}{lllll}
\hline Virus & $\begin{array}{l}\text { Infect } \\
\text { Cats? }\end{array}$ & $\begin{array}{l}\text { Clinical } \\
\text { Disease } \\
\text { In Cats }\end{array}$ & $\begin{array}{l}\text { Protect Cats } \\
\text { Against FIPV? }\end{array}$ & $\begin{array}{l}\text { Sensitize Cats } \\
\text { To FIPV? }\end{array}$ \\
\hline FECV & yes & enteritis & no & yes \\
TGEV & yes & none & no & no \\
CCV & yes & none & no & no \\
$229 E$ & yes & none & no & no \\
CVLP & yes & none & no & no \\
\hline
\end{tabular}




\section{PROTEINS OF FELINE CORONAVIRUSES}

FIP viruses like other coronaviruses contain 3 major proteins, the small envelope glycoprotein "El" (25 to 32 kilodaltons), the slightly larger nucleocapsid protein "N" (40-43 kilodaltons), and the large peplomer glycoprotein "E2" or "P" (160 to 180 kilodaltons). $10,12,13,41,44$ In a study of the virion polypeptides in immune complexes found in cats infected with FIP virus, Horzinek et al. ${ }^{12}$ found 3 major envelope E proteins (p32, p30, and p27), two N proteins (p43 and P40), and a singular peplomer protein ( $p 83)$. The peplomer protein was believed to be either a proteolytic split product or an intracellular precursor of the higher molecular weight glycoprotein $(185 \mathrm{kd})$.

Monoclonal antibodies against each of these 3 major proteins have been produced by Fiscus et al. ${ }^{10}$ These investigators showed that a high degree of correlation (85.7\%) existed between a competitive ELISA test using monoclonal antibodies against the $\mathrm{E} 1$ glycoprotein and the immunofluorescent antibody assay. A lower degree of correlation (65.5\%) occurred with monoclonals against the $\mathrm{N}$ protein, and little if any correlation (2.4\%) occurred with the E2 or peplomer glycoprotein. It is believed that the E2 protein is the one responsible for attachment to cells, and hence carries the host specificity or lack thereof as the case may be.

A comparison of the antigenic relationships amoung homologous structural polypeptides of porcine, feline, and canine coronaviruses was made by Horzinek and his co-workers. ${ }^{13}$

\section{THE IMMUNE RESPONSE TO FELINE CORONAVIRUSES IN CATS}

Humoral immunity. In cats exposed to FIP virus via aerosol, intranasal drops, or by inoculation develop antibody titers in sera starting approximately 7 days after exposure. ${ }^{39,47}$ The antibody titer continues to rise until it plateaus at about 3 to 4 weeks after exposure. Clinical disease usually does not occur during the first 2 weeks of infection, or if it does, it is usually limited to a mild and transient febrile response, and possibly a day or 2 of listlessness and inappetence. After 2 weeks, and of ten approaching 3 weeks after exposure, an insidious onset of clinical disease occurs, consisting of fever, inappetence, depression, and progressive weight loss. There also may be progressive accumulation of fluid within the peritoneal, pericardial, or thoracic cavities.

The serum antibody response occurs first and strongest to the $\mathrm{N}$ protein, the response to the $\mathrm{E}$ protein was less strong and slower to occur, and the weakest humoral antibody response occurred against the $P$ or peplomer protein. 10,12

Cell-mediated immunity. It appears that cell-mediated immunity (CMI) may play a significant role in acquired resistance to FIP virus. ${ }^{33}$ Cats with high humoral antibody titers to FIP viruses of ten are still susceptible to clinical disease. Little is known about details of CMI to coronaviruses in the cat.

Immune enhancement of disease. Attempts have been made to produce inactivated vaccines from various infectious fluids such as peritoneal fluid or infected cell cultures. The resulting vaccines produce antibody responses in vaccinated cats, but when these vaccinated cats were exposed to virulent virus, the vaccinates developed clinical FIP within the first few days while non-vaccinated control cats did not develop clinical FIP until 10-21 days after exposure. Vaccination of cats with strains of FIPV such as UCD 1 only "sensitized" to subsequent exposure to that strain of virus or other strains of virus rather than to stimulate immunity with protection against serious disease.

Weiss and Scott 45,49 demonstrated that FIPV-UCD 1 requires the presence of antibodies in the serum before secondary infection or the main disease process occurs in cats infected with FIPV. The C3 component of complement also in involved in 
the disease process. In other words, the basic lesion and disease process is antibody mediated and complement dependent. Circulating immune complexes can occur within the blood stream of infected cats. These continue to rise in number throughout the course of the disease, as the antibody titer rises. These complexes can be deposited in the renal glomeruli, or they can persist in the infected animal during the terminal stages of infection when there is complement depletion. ${ }^{17}$ Immune complexes from sera and ascitic fluids contain proteins as well as proteolytic fragments of all 3 major proteins comprising the FIP virus. ${ }^{12}$ The immunologic phenomena of the effusive form of FIP have been discussed by Pedersen and Boyle. ${ }^{29}$

There are similarities between the immune enhancement to FIP in cats and the immune enhancement observed with dengue fever viruses in humans. ${ }^{49}$ With dengue hemorrhagic fever viruses, the first infection appears to produce an acute infection with fever but usually not serious consequences. When reinfection of that individual occurs with another serotype of dengue fever virus, an immune-enhanced hemorrhagic disease results which is much more severe than the original infection.

The exact mechanism of the immune enhancement in the cat is not known. It is speculated that it may involve the increased infectivity of monocytes in the blood by antigen-antibody complexes. Viremia in FIP is strictly cell-associate, involving circulating monocytes which carry the virus into perivascular tissues as these monocytes attach to vessel walls and migrate through the vein wall, ${ }^{47}$ resulting in vascular and perivascular lesions. ${ }^{11,48}$

Maternally derived passive immunity. In colonies or catteries where FIP virus is endemic, Stoddart et al. ${ }^{42}$ and Pedersen and Floyd ${ }^{33}$ have shown that kittens born to queens with coronavirus antibodies, presumably to FIPV, transfer antibodies via the colostrum to their newborn kittens. These passive antibody titers decline at the normal rate for passive antibodies, and between 4 and 8 weeks of age most kittens apparently become infected from the immune carrier mother cat and develop an active antibody titer which then persists. These kittens usually do not show symptoms of disease.

\section{POSSIBLE IMMUNIZATION APPROACHES TO FIP}

The need for an effective vaccine against FIP is quite apparent. Because of the unusual nature of the immune response against this virus, the prospects of developing an effective vaccine are far from certain. Some of the approaches that have been tried or proposed include the following.

Inactivated whole virus vaccine. Attempts to produce an inactivated whole virus vaccine to date have been unsuccessful. Sensitization rather than immunization has been a problem, and cell-mediated immunity (which is only weakly produced by inactivated vaccines) is not produced in sufficient quantity to provide protection. 33

Inactivated subunit vaccine. Studies to isolate the peplomer protein from FIPV and to use that as an antigen for a vaccine have to date been unsuccessful. ${ }^{39}$ The sequencing of the genome that codes for this protein provides a possible method for synthesizing large quantities of antigen through recombinant DNA technology.

Live homologous FIP virus vaccine. Theoretically one might be able to find a strain of virus that (1) does not sensitize, (2) does not produce clinical disease, and (3) provides protection against virulent virus. Attempts have been made to identify such a virus among the many naturally occurring strains of coronaviruses that infect cats. By giving small amounts of virus, Pedersen and Black 27 were able on occassion to produce a cat that developed antibody titers against FIPV without developing clinical disease. However, when these antibody positive cats were challenged with FIPV-Black strain no protection occurred in vaccinated cats. In fact, the vaccinated cats had an enhanced response to the FIPV. The same dose of virus that produced immunity in some cats resulted in fatal FIP infection in other cats. 
Pedersen and Floyd ${ }^{33}$ studied several strains of virus for potential immunogens. Their UCD-2 strain infected cats without producing disease, but it also sensitized them so that subsequent challenge with virulent virus resulted in enhance FIP. UDC-3 and UCD-4 strains infected cats and produced fatal FIP in some cases, but resulted in subclinical infection in other cats.

Heterologous live virus vaccine. Other members of the same antigenic cluster of viruses (TGE, CCV, and HCV-229E) have been studied for their ability to stimulate neutralizing antibody titers, and to produce immunity or protection in the vaccinated cat. Initial attempts to immunize cats against FIP with TGE virus of swine were unsuccessf ul. 34,36

Infection of cats by injection or by the oronasal route with human coronavirus $229 \mathrm{E}$ resulted in homologous neutralizing antibody responses but no clinical disease. ${ }^{4}$ Heterologous neutralizing antibodies were not detected in these cats against CCV or TGEV. No protection was produced against FIPV, nor were these cats sensitized to FIPV.

Experimental infection of cats with canine coronavirus resulted in infection, shed of virus, and seroconversion against the homologous CCV. ${ }^{6}$ Heterologous titers against TGEV by the kenetics ELISA test only occurred after repeated oronasal exposures to CCV. Protection against FIPV was not produced by CCV, and sensitization against FIPV challenge did not occur.

The FECV strains have been suggested to be separated viruses from FIPV. However, many investigators feel the FECV strains are merely biotypes of FIP rather than heterologous viruses.

Recombinant vaccine. As more information is obtained about the detailed structure of the FIP virus, recombinant vaccines of various types will undoubtedly be investigated. A comparison of the genotypes of different strains of virus will be important in comparison of these strains. As with so many aspects of FIP, it is impossible to accurately predict the outcome of such studies.

\section{SUMMARY}

Feline infectious peritonitis (FIP) is caused by one of several strains of feline coronaviruses which are grouped into 2 general types of viruses. Infection of cats with FIP virus results in production of serum antibodies which may be protective in conjuction with cell mediated immunity, may provided no protection at all, or may produce an immune enhancement to subsequent exposure to another FIP virus or a recrudesence of the original infecting virus. Attempts at immunization of cats against FIP with inactivated or live FIP viruses have been generally unsuccessful, and of ten sensitizing the cat through immune enhancement rather than providing protection. Heterologous live virus vaccines using viruses of the same antigenic cluster (transmissible gastroenteritis of swine, canine coronavirus, and human coronavirus 229E) have failed to provide protection against FIP virus. Further research into the exact mechanism of protection and immune enhancement is needed in order to understand ways of producing an effective and safe vaccine.

\section{REFERENCES}

1. Barlough JE: Serodiagnostic aids and management practice for feline retrovirus and coronavirus infections. Vet Clinics North America: Small Animal Practice 14(5):955-969, 1984.

2. Barlough JE: Cats, coronaviruses and coronavirus antibody tests. J Small Anim Pract 26:353-362.

3. Barlough JE, Jacobson RH, Downing DR, Marcella KL, Lynch TJ, Scott FW: Evaluation of a computer-assisted, kinetics-based enzyme-linked immunosorb- 
ent assay for detection of coronavirus antibodies in cats. J Clin Microbiol 17:202-217, 1983.

4. Barlough JE, Johnson-Lussenburg CM, Stoddart CA, Jacobson RH, Scott FW: Experimental inoculation of cats with human coronavirus $229 \mathrm{E}$ and subsequent challenge with feline infectious peritonitis virus. Can J Comp Med 49:303$-307,1985$.

5. Barlough JE, Stoddart CA: Feline infectious peritonitis, in Scott FW (ed): Contemporary Issues in Small Animal Practice 3:93-108, Churchill Livingstone, New York, 1986.

6. Barlough JE, Stoddart CA, Sorresso GP, Jacobson RH, Scott FW: Experimental inoculation of cats with canine coronavirus and subsequent challenge with feline infectious peritonitis virus. Lab Anim Sci 34:592-597, 1984.

7. Black JW: Recovery and in-vitro cultivation of a coronavirus from laboratoryinduced cases of feline infectious peritonitis (FIP). VM SAC 75:811-814, 1982.

8. Dea S, Roy RS, Elazhary MASY: Coronavirus-like particles in the feces of a cat with diarrhea. Can Vet J 23:153-155, 1982.

9. Evermann JF, Baumgartener L, Ott RL, Davis EV, McKeirnan AJ: Characterization of a feline infectious peritonitis virus isolate. Vet Pathol 18:256-265, 1981.

10. Fiscus SA, Teramoto YA, Mildbrand MM, Knisley CV, Winston SE, Pedersen NC: Competitive enzyme immunoassays for the rapid detection of antibodies to feline infectious peritonitis virus polypeptides. J Clin Microbiol 22:395-401, 1985.

11. Hayashi T, Goto N, Takahashi $R$, Fujiwara K: Systemic vascular lesions in feline infectious peritonitis. Jap J Vet Sci 39:365-377, 1977.

12. Horzinek MC, Ederveen J, Egberink H, Jacobse-Geels HEL, Niewold T, Prins J: Virion polypeptide specificity of immune complexes and antibodies in cats inoculated with feline infectious peritonitis virus. Am J Vet Res 47:754-761, 1986.

13. Horzinek MC, Lutz H, Pedersen NC: Antigenic relationship among homologous structural polypeptides of porcine, feline, and canine coronaviruses. Infect Immun 37:1148-1155, 1982.

14. Horzinek MC, Osterhaus ADME: Feline infectious peritonitis: A coronavirus disease of cats. J Small Anim Pract 19:623-630, 1978.

15. Horzinek MC, Osterhaus ADME: The virology and pathogenesis of feline infectious peritonitis. Arch Virology 59:1-15, 1979.

16. Hoshino Y, Scott FW: Coronavirus-like particles in the feces of normal cats. Arch Virology 63:147-152, 1980.

17. Jacobse-Geels HEL, Daha MR, Horzinek MC: Isolation and characterization of feline $\mathrm{C} 3$ and evidence for the immune complex pathogenesis of feline infectious peritonitis. J Immunol 125:1606-1610, 1980.

18. McKeirnan AJ, Evermann JF, Hargis A, Miller LM, Ott RL: Isolation of feline coronaviruses from two cats with diverse disease manifestations. Feline Practice 11(3):16-20, 1981.

19. O'Reilly KJ, Fishman LM, Hitchcock LM: Feline infectious peritonitis: Isolation of a coronavirus. Vet Rec 104:348, 1979.

20. Osterhaus ADME, Horzinek MC, Reynolds DJ: Seroepidemiology of feline infectious peritonitis virus infections using transmissible gastroenteritis virus as antigen. Zbl Vet Med B 24:835-841, 1977.

21. Osterhaus ALDE, Horzinek MC, Wirahadiredja RMS: Feline infectious peritonitis virus. II. Propagation in suckling mouse brain. Zbl Vet Med B 25:301-307, 1978.

22. Ott RL: Feline infectious peritonitis. In Pratt, PW (ed): Feline Medicine. American Veterinary Publications, Santa Barbara, 1983, pp 116-123.

23. Pedersen NC: Morphologic and physical characteristics of feline infectious peritonitis virus and its growth in autochthonous peritoneal cell cultures. Am J Vet Res 37:567-572, 1976.

24. Pedersen NC: Serologic studies of naturally occurring feline infectious peritonitis. Am J Vet Res 37:1449-1453, 1976. 
25. Pedersen NC: Feline infectious peritonitis and feline enteric coronavirus infections. Feline Practice 13(4):13-19 and 13(5):5-20, 1983.

26. Pedersen NC: Feline coronavirus infections. In Greene, CE (ed): Clinical Microbiology and Infectious Diseases of the Dog and Cat. W.B. Saunders Co., Philadelphia, 1984, pp514-526.

27. Pedersen NC, Black JW: Attempted immunization of cats against feline infectious peritonitis, using avirulent live virus or sublethal amounts of virulent virus. Am J Vet Res 44:229-234, 1983.

28. Pedersen NC, Black JW, Boyle JF, Evermann JF, McKeirnan AJ, Ott RL: Pathogenic differences between various feline coronavirus isolates. Adv Exp Med Biol 173:365-380, 1984.

29. Pedersen NC, Boyle JF: Immunologic phenomena in the effusive form of feline infectious peritonitis. Am J Vet Res 41:868-876, 1980.

30. Pedersen NC, Boyle JF, Floyd K: Infection studies in kittens utilizing feline infectious peritonitis virus propagated in cell culture. Am J Vet Res 42:363$367,1981$.

31. Pedersen NC, Boyle JF, Floyd K, Fudge A, Barker J: An enteric coronavirus infection of cats and its relationship to feline infectious peritonitis. Am $\mathbf{J}$ Vet Res 42:368-377, 1981.

32. Pedersen NC, Evermann JF, McKeirnan AJ, Ott RL: Pathogenicity studies of feline coronavirus isolates 79-1146 and 79-1683. Am J Vet Res 45:2580-2585, 1984.

33. Pedersen NC, Floyd K: Experimental studies with three new strains of feline infectious peritonitis virus: FIPV-UCD2, FIPV-UCD3, and FIPV-UCD4. Compendium on Continuing Education 7:1001-1011, 1985.

34. Pedersen NC, Ward J, Mengeling WL: Antigenic relationship of the feline infectious peritonitis virus to coronaviruses of other species. Arch Virology 58:45-53, 1978.

35. Reynolds DJ, Garwes DJ, Gaskell CJ: Detection of transmissible gastroenteritis virus neutralizing antibody in cats. Arch Virology 55:77-86, 1977.

36. Reynolds DJ, Garwes DJ: Virus isolation and serum antibody responses after infection of cats with transmissible gastroenteritic virus. Arch Virology 60:161-166, 1979.

37. Scott FW; FIP antibody test--Interpretation and recommendations. JAVMA 175:1164-1168,1979.

38. Scott FW: Feline infectious peritonitis and other feline coronaviruses, in Kirk RW (ed): Current Veterinary Therapy IX, pp1059-1062. W.B.Saunders, Philadelphia, 1986.

39. Scott FW: Cornell University, Unpublished data, 1986.

40. Scott FW, Weiss RC, Post JE, Gilmartin JE, Hoshino Y: Kitten mortality complex (neonatal FIP?). Feline Practice 9:44-56, 1979.

41. Siddell S, Wege H, ter Meulen V: The structure and replication of coronaviruses. Curr Top Microbiol Immunol 99:131-163.

42. Stoddart CA, Barlough JE, Scott FW: Experimental studies of a coronavirus and coronavirus-like agent in a barrier-maintained feline breeding colony. Arch Virology 79:85-94, 1984.

43. Stoddart CA, Scott FW: Cornell University, Unpublished data, 1986.

44. Wege H, Siddell S, Meulen V: The biology and pathogenesis of coronaviruses. Curr Top Microbiol Immunol 99:165-200, 1982.

45. Weiss RC, Dodds WJ, Scott FW: Disseminated intravascular coagulation in experimentally induced feline infectious peritonitis. Am J Vet Res 41:663-671, 1980.

46. Weiss RC, Scott FW: Laboratory diagnosis of feline infectious peritonitis. Feline Practice 10(2):16-22, 1980.

47. Weiss RC, Scott FW: Pathogenesis of feline infectious peritonitis: Nature and development of viremia. Am J Vet Res 42:382-390, 1981.

48. Weiss RC, Scott FW: Pathogenesis of feline infectious peritonitis: Pathologic changes and immunofluorescence. Am J Vet Res 42:2036-2048, 1981.

49. Weiss RC, Scott FW: Antibody-mediated enhancement of disease in feline infectious peritonitis: comparisons with dengue hemorrhagic fever. Comp Immun Microbiol Infect Dis 4:175-189, 1981. 